Willow Verkerk

\title{
On Love, Women, and Friendship: Reading Nietzsche with Irigaray
}

\begin{abstract}
This essay examines Nietzsche's accounts of love and the gender troubles of friendship. In many passages, Nietzsche situates love as an impairment to friendship. In particular, he believes that erotic or sexual love, understood as a drive that seeks to possess and control the other, prevents two people from entering into the shared project of friendship. Nietzsche implies that gender roles, and the cultural expectations associated with these types, make friendship very difficult between women and men. The reason why women in Nietzsche's account cannot move from love relationships into friendship is because they are primarily esteemed for their fulfillment of gender stereotypes. In order to avoid the perils of assimilation, pointed to by Nietzsche, it is imperative to develop an ethics of friendship that changes the way people approach and love one another. Luce Irigaray present such an alternative with her account of wonder. She argues that recognition requires a negative movement in which one acknowledges one's limits in understanding the other. Irigaray designates a transformative and activist potential to love, as a benefit to friendship in its erotic and practical qualities. She claims that when love is expressed alongside the passion of wonder there is a stronger potential for recognition between two people. With the assistance of Irigaray, this essay questions Nietzsche's assessment that love is an impasse to friendship by asking if love need be as assimilating as Nietzsche proposes.
\end{abstract}

Keywords: Love, friendship, women, misogyny, sexual difference.

Zusammenfassung: Dieser Aufsatz behandelt Nietzsches Überlegungen zur Liebe und zum Unbehagen der Geschlechter in Freundschaftsbeziehungen. Vielerorts in seinem Werk stellt Nietzsche Liebe als Beeinträchtigung der Freundschaft dar. Im Besonderen meint er, erotische bzw. sexuelle Liebe, verstanden als Trieb zur Besitzergreifung und Kontrolle des andern, hindere zwei Menschen daran, in das gemeinsame Projekt einer Freundschaft einzutreten. Er setzt dabei voraus, dass die jeweiligen Geschlechterrollen und die damit verbundenen kulturellen Erwartungen Freundschaft zwischen Frauen und Männern schwierig machen. Der Grund, aus dem Frauen nach Nietzsche nicht von Liebesbeziehungen zu Freundschaften übergehen können, liegt darin, dass sie vor allem für ihre Erfüllung von Geschlechter-Stereotypen wertgeschätzt werden. Um die Gefahren einer solchen Rollenanpassung zu vermeiden, ist es geboten, eine Ethik der Freundschaft zu entwickeln, die die Art der Begegnung und der Liebe zwischen Menschen verändert. Luce Irigaray bietet mit ihrem Begriff der Verwunderung eine solche Alternative an. Anerkennung, so Irigaray, verlangt eine negative Bewegung, in der man seine eigenen Grenzen eingesteht, den anderen zu verstehen. Sie umreißt ein transformatives und aktivistisches Potential der Liebe zu Gunsten der 
Freundschaft in ihren erotischen und praktischen Qualitäten. Irigaray behauptet, wenn Liebe zusammen mit der Passion der Verwunderung ausgedrückt werde, gebe es ein stärkeres Potential der Anerkennung unter zwei Menschen. Vor dem Hintergrund dieser Überlegungen von Irigaray stellt dieser Aufsatz Nietzsches Annahme in Frage, Liebe führe Freundschaft in die Sackgasse, indem er der Frage nachgeht, ob Liebe wirklich eine solche Rollenanpassung braucht, wie Nietzsche es darstellt.

Schlagwörter: Liebe, Freundschaft, Frauen, Frauenfeindlichkeit, Unterschied der Geschlechter.

\section{Introduction}

Weiberf ein de. - „Das Weib ist unser Feind“ - wer so als Mann zu Männern spricht, aus dem redet der ungebändigte Trieb, der nicht nur sich selber, sondern auch seine Mittel hasst. (M 346) ${ }^{1}$

The above quote from Morgenröthe, originally attributed to Schopenhauer (KSA 14.220), is one instance of many in which Nietzsche critiques the dysfunction of the male psyche while concurrently framing the female as a lower type of human being and, in this instance, as an instrument for male enjoyment. This leaves the reader confused as to Nietzsche's intentions: does he want men to stop conceiving of women as enemies solely for the sake of men? Is Nietzsche critiquing the misogynistic tradition of male dominance or is he merely making cultural and psychological diagnoses?

In this essay, Nietzsche's accounts of love and the gender troubles of friendship will be examined in addition to a selection of his writings on women. In many passages, Nietzsche situates love as an impairment to friendship. In particular, he believes that erotic or sexual love, understood as a drive that seeks to possess and control the other, prevents two people from entering into the shared project of friendship. The passionate disposition of the lover, and especially the female lover, inhibits knowledge-seeking and self-reflection in Nietzsche's writings. Nietzsche suggests that in love relationships the power disparity between lovers and the expectations associated with the proximity of love disrupt the possibility of mutual understanding. He writes about a lack of generosity from men which makes it difficult for women to gain the power and intelligence necessary to develop the characteristics that support friendship. Nietzsche implies that gender roles, and the cultural expectations associated with these types, make friendship very difficult between women and men.

1 I use the following translations for Nietzsche's works: Beyond Good and Evil/On the Genealogy of Morality, trans. Adriano Del Caro, Stanford 2014; Human, All Too Human, trans. R. J. Hollingdale, Cambridge 1986; The Gay Science, trans. Walter Kaufmann, New York 1974; Thus Spoke Zarathustra, trans. Graham Parkes, Oxford 2005. 
In Also sprach Zarathustra, Nietzsche claims that friendship is not yet possible for women. Women, according to Nietzsche, are limited to loving and acting as slaves and tyrants (Za I, Vom Freunde). Nietzsche's writings on women reveal his own observations about the lack of autonomy women struggled with during his time due to gender inequalities. For example, Nietzsche states that women are both "slave laborers and prisoners" (GM III 18). However, Nietzsche also asserts that sexual difference and the instincts associated with erotic love necessitate the predominance of male friendship and the absence of female friendships with men and with each other (FW 363; Za I, Vom Freunde). In Jenseits von Gut und Böse, Nietzsche's assessment of women turns so vitriolic that one wonders if he has not himself become the enemy of women that he warns about in Morgenröthe (M 346).

In Nietzsche's account of (heterosexual) love, erotic love and the limited opportunities for mutual understanding through esteem recognition perpetuate assimilation. The reason why women in Nietzsche's account cannot move from love relationships into friendship is because they are primarily esteemed for their fulfillment of gender stereotypes. In order to avoid the perils of assimilation, pointed to by Nietzsche, it is imperative to develop an ethics of friendship that changes the way people approach and love one another. Luce Irigaray presents such an alternative with her account of wonder. She argues that recognition requires a negative movement in which one acknowledges one's limits in understanding the other. Irigaray designates a transformative and activist potential to love, as a benefit to friendship in its erotic and practical qualities. When love is expressed alongside the passion of wonder, she claims that there is a stronger potential for recognition between two people. With the assistance of Irigaray, this essay questions Nietzsche's assessment that love is an impasse to friendship by asking if love need be as assimilating as Nietzsche proposes. Following Irigaray, this paper illustrates that the concept of love and its association with male and female gender roles requires a re-evaluation that Nietzsche was not able to fully conceptualize.

\section{Nietzsche on Love as Assimilation}

Throughout his writings on women Nietzsche implies, with a provocative and critical voice, that the kind of love that governs human relationships advantages men and harms women. In Nietzsche's account of love, the greatest recognition that men and women are able to achieve is a kind of esteem experienced through the fulfillment of gender roles. Nietzsche's assessments of heterosexual relationships expose the exploitative character of romantic and erotic love, but do not provide solutions to this predicament.

In Die fröhliche Wissenschaft Nietzsche writes that erotic or sexual love is really a drive toward possession that "has been glorified and deified" (FW 14) by those in 
search of acquiring something for self-enhancement. Nietzsche is speaking about what Irigaray will call "love of the same": it involves reduction and incorporation "through our knowledge, our affection, our customs. At the limit, we no longer see the other, we no longer hear the other, we no longer perceive the others. The other is part of us."2 Love of the same, according to Irigaray, assimilates the other into oneself. The possessive drive is a characteristic strongly associated with male love in Nietzsche's writings. In Jenseits von Gut und Böse (JGB 194), for example, Nietzsche explores the diversity ("Verschiedenheit") of men through how three different kinds of men attempt to possess women:

In Betreff eines Weibes zum Beispiel gilt dem Bescheideneren schon die Verfügung über den Leib und der Geschlechtsgenuss als ausreichendes und genugthuendes Anzeichen des Habens, des Besitzens; ein Anderer, mit seinem argwöhnischeren und anspruchsvolleren Durste nach Besitz, sieht das „Fragezeichen“, das nur Scheinbare eines solchen Habens, und will feinere Proben, vor Allem, um zu wissen, ob das Weib nicht nur ihm sich giebt, sondern auch für ihn lässt, was sie hat oder gerne hätte -: so erst gilt es ihm als „,besessen“. Ein Dritter aber ist auch hier noch nicht am Ende seines Misstrauens und Habenwollens, er fragt sich, ob das Weib, wenn es Alles für ihn lässt, dies nicht etwa für ein Phantom von ihm thut: er will erst gründlich, ja abgründlich gut gekannt sein, um überhaupt geliebt werden zu können, er wagt es, sich errathen zu lassen -. Erst dann fühlt er die Geliebte völlig in seinem Besitze, wenn sie sich nicht mehr über ihn betrügt, wenn sie ihn um seiner Teufelei und versteckten Unersättlichkeit willen eben so sehr liebt, als um seiner Güte, Geduld und Geistigkeit willen. (JGB 194)

Nietzsche states that the masculine need to possess and control women is expressed through male sexual domination, the demand for personal sacrifice from the female partner, and the obtainment of unconditional acceptance from her for his most dislikeable characteristics. Nietzsche is pointing to a problem that exists in love between men and women without making any suggestions for improvement. However, there is some ethical merit to Nietzsche's reflections because they can help his readers to acknowledge the romantic idealizations of love as well as the performative failures of gender roles. Also, his characterization of friendship in FW 14, as a higher goal that moves beyond the assimilating expressions of love, suggests that he considers friendship possible for women, although more difficult to achieve. This claim is further supported by his comments on men and women in Zarathustra. Nietzsche writes:

\footnotetext{
Allzulange war im Weibe ein Sclave und ein Tyrann versteckt. Desshalb ist das Weib noch nicht der Freundschaft fähig: es kennt nur die Liebe.

In der Liebe des Weibes ist Ungerechtigkeit und Blindheit gegen Alles, was es nicht liebt. Und auch in der wissenden Liebe des Weibes ist immer noch Überfall und Blitz und Nacht neben dem Lichte.

Noch ist das Weib nicht der Freundschaft fähig: Katzen sind immer noch die Weiber, und Vögel. Oder, besten Falles, Kühe.
}

2 Luce Irigaray, Key Writings, London 2004, p. 24. 
Noch ist das Weib nicht der Freundschaft fähig. Aber sagt mir, ihr Männer, wer von euch ist denn fähig der Freundschaft?

Oh über eure Armuth, ihr Männer, und euren Geiz der Seele! (Za I, Vom Freunde)

Nietzsche is writing that women are animals, but he is also stating that men are miserly when it comes to women. In fact, the close-fistedness of men is elaborated on through Nietzsche's association of women with different kinds of animals: birds, cats, and cows. ${ }^{3}$ Nietzsche implies that women do not simply behave like these animals; rather, men conceptualize these roles and push women into them (FW 68; JGB 237a).

Nietzsche views tyranny and slavery to be part of love, insofar as it is based upon the struggle to possess and be possessed. There is no equality in Nietzsche's account of love or a shared higher goal to regulate the possessive drives of lovers. Love relationships have as their goals the possession of the two people that are a part of the relationship and, for this reason, lack the competitive reciprocity of Nietzsche's agonistic friends and the mentor-student relationship of the bestowing friendship. ${ }^{4}$ In Nietzsche's account, male and female gender roles play a key part in governing love relationships and preventing them from becoming friendships.

Nietzsche had some early insights into the power dynamics between the genders and how they stifle female autonomy. Nietzsche suggests that women, who are most likely to be possessed and assimilated in love, over-identify with their lover and the experience of love. In this regard, he states that the love a woman has for her male partner is a faith and the only faith that she has (FW 363). A more developed account of how female identity is confined through love is explained by Simone de Beauvoir:

She at first sought in love a confirmation of what she was, of her past, of her personality; but she also involves her future in it, and to justify her future she puts it in the hands of one who possesses all values. Thus she gives up her transcendence, subordinating it to that of the essential other, to whom she makes herself vassal and slave. It was to find herself, to save herself, that she lost herself in him in the first place; and the fact is that little by little she does lose herself in him wholly; for her the whole of reality is in the other. ${ }^{5}$

When Beauvoir states that the entire reality of a woman is in the world of her male partner, she makes a similar point to that of Nietzsche when he states that the love that a woman has for her male partner is an all-encompassing faith. In Zarathustra,

3 In JGB 237a Nietzsche states that men treat women like birds because women appear vulnerable to them, like wild creatures that they have to cage to ensure that they do not fly away. He calls women cats because he believes, like cats, women are beautiful and dangerous, more suffering, "in need of love and more doomed to disappointment than any animal” (JGB 239, KSA 5.178). Women are cows for Nietzsche when they express confidence, calmness, and a steady nature (FW 67).

4 For an account of friendship in Nietzsche see Willow Verkerk, Nietzsche's Agonistic Ethics of Friendship, in: Symposium. Canadian Journal for Continental Philosophy 20.2 (Fall 2016), pp. 22-41. 5 Simone de Beauvoir, The Second Sex, trans. and ed. Parshley, New York 1957, p. 651. 
Nietzsche re-affirms this observation when Zarathustra states, „Der Mann fürchte sich vor dem Weibe, wenn es liebt: da bringt es jedes Opfer, und jedes andre Ding gilt ihm ohne Werth." (Za I, Von alten und jungen Weiblein) Nietzsche implies that the female need to be subsumed in the world of the man she loves means that women seek their power within love relationships instead of elsewhere. Women may obtain power, esteem, and thus personal significance subversively through becoming a function of a man that is absent in him such as "his purse, his politics or his sociability" (FW 119) or as an object of desire. However, in Also sprach Zarathustra, the suggestion is made that women are limited in perspective because they over-identify with their love relationship. „In der Liebe des Weibes ist Ungerechtigkeit und Blindheit gegen Alles, was es nicht liebt.“ (Za I, Vom Freunde) Nietzsche thinks that a woman's love relationship is her primary source of self-value and, as such, she cannot look beyond it. This is why Nietzsche writes that women treat those who they do not love with a lack of interest and fairness and why they are not yet capable of friendship.

Although there is struggle in Nietzsche's account of love relationships, the drive to possess and be possessed disallows for the kind of recognition based on respect and wonder that are vital for Irigaray. In order for women to be given value or significance, Nietzsche suggests that they must search out a position that is a function of a man's life, as a wife, a mother, or as an object of worship. They have to find themselves a place of esteem within the already existing order of things which is patriarchal, although Nietzsche does not use this term. In Nietzsche's writings, 'woman' vacillates between servitude and idolatry without having the ability or opportunity to consider what could be a "depth for her surface" (Za I, Von alten und jungen Weiblein) that is not defined by a man or by the world of men. ${ }^{6} \mathrm{~A}$ woman may be positively appraised for her fulfillment of feminine characteristics, but Nietzsche suggests that implicit to this appraisal is the experience of misrecognition that she struggles with privately in relationships with herself, as well as her relationships with men and other women (FW 68). Esteem recognition through the fulfillment of gender role is the only kind of recognition presented as an option for women in Nietzsche's philosophy.

\section{Women in Jenseits von Gut und Böse}

Nietzsche's writings on women have significant variation and for this reason, it is easy to dismiss him as a philosopher bound by cultural and time dependent norms, norms about women and men that are expressed by him literally throughout his books.

6 Nietzsche writes: „Und gehorchen muss das Weib und eine Tiefe finden zu seiner Oberfläche.“ (Za I, Von alten und jungen Weiblein) 
However, this is an incomplete approach to reading Nietzsche: many of his passages on women exude play, confrontation, and provocation. ${ }^{7}$ He writes to force reflection and reaction. Granted, there is good evidence from which to argue that he is severely limited in this area of his thought. For example, Nietzsche appears to express his conviction that women are indeed the inferior sex who "have the instinct for a secondary role" (JGB 145). In Jenseits von Gut und Böse, he includes a series of aphorisms on women that sound rather misogynistic. In a footnote to his translation, Walter Kaufmann states that Nietzsche's writings on women that follow JGB 231 are embarrassing and "wrong." As Carol Diethe has pointed out, Nietzsche shares many of the beliefs about women prevalent in the Wilhelmine society of his time, one being that women who pursue a vocation outside of motherhood are deficient in some way. ${ }^{9}$

Nietzsche is at times caught up in his own cultural and personal burden concerning "woman as such” (“,Weib an sich“”) as he admits in JGB 231. He explains that when it comes to particular topics, such as one's beliefs about woman and man, one cannot relearn, but only "finish learning." However, he also states that the convictions one has about 'woman' can be viewed later as "steps to self-knowledge, sign posts to the problem we are-rather, to the great stupidity ("Dummheit") we are, to our spiritual fatum, to what is unteachable very 'deep down'” (JGB 231). This admission before Nietzsche writes a series of his seemingly most misogynistic aphorisms invites the reader to question the validity of Nietzsche's 'truths' on women, and in doing so, also question oneself on the topic. Nietzsche's disclosure that convictions about man and woman reveal the extent of one's "stupidity" means that he considers individual beliefs about the gender roles to carry within them great prejudice.

Nietzsche is taking a less sympathetic tone to women in Jenseits von Gut und Böse as compared to his writings on women in Die fröhliche Wissenschaft. In the spirit of the no-saying deconstructive aim of JGB, Nietzsche is expressing his thoughts about women with a dissonance that requests a response from the reader. His writings about women that follow JGB 231 are particularly harsh and even previous to expressing his 'truths' about 'woman,' he makes some pointed remarks. But, within the cruelty of these writings about women Nietzsche continues to offer insightful thoughts on the difficulties of gender roles and the challenges they present to friendship and love relationships. Perhaps this is because, as Lynne Tirrell suggests, within those writings

7 Derrida has explored how Nietzsche attempts to become 'woman' through his use of styles and in doing so expresses both anti-feminist and feminist perspectives (Jacques Derrida, Spurs: Nietzsche's Styles, trans. Barbara Harlow, Chicago 1979). See also Oliver's critique of Derrida in Kelly Oliver, Nietzsche's Woman: The Postructuralist Attempt To Do Away with Women, in: Radical Philosophy 48 (1988), pp. 25-29.

8 Beyond Good and Evil, trans. Walter Kaufmann, New York 1966, p. 167, footnote 31.

9 Carol Diethe, Nietzsche's Women: Beyond the Whip, Berlin/NewYork 1996, p. 41. 
of Nietzsche's which seem most misogynistic are the seeds for questioning and even undermining the presumptions of that misogyny. ${ }^{10}$

In a series of three short aphorisms in JGB, Nietzsche reflects on the psychological turmoil that women struggle with in terms of their relationship to 'woman':

Das Weib lernt hassen, in dem Maasse,in dem es zu bezaubern - verlernt. (JGB 84)

Die gleichen Affekte sind bei Mann und Weib doch im Tempo verschieden: deshalb hören Mann und Weib nicht auf, sich misszuverstehn. (JGB 85)

Die Weiber selber haben im Hintergrunde aller persönlichen Eitelkeit immer noch ihre unpersönliche Verachtung - für „das Weib“. (JGB 86)

Nietzsche is suggesting in aphorism 84 that women require charms to captivate others, to love and to be loved. Without skills of enchantment women cannot be admired because women are valued primarily for their appearances. Women are vain according to Nietzsche and their vanity, which is connected to the arts of physical beauty, is their source of power as well as a link to their "secondary role" (JGB 145). Yet, women also have contempt for the 'woman' that they cannot live up to (JGB 86). When Nietzsche writes that women share an impersonal contempt for 'woman' it seems that he is pointing to a share in the collective misogyny that men and women have for the symbol of 'woman.' These three aphorisms are implying that women struggle with a pressure to be as feminine as possible, yet also feel great dislike for the ideal they are attempting to become. It seems fair to assume then that Nietzsche is linking the difference in emotional "tempo" that causes misunderstandings between men and women to the identity struggles that women have in relation to their gender roles.

Later, in the passages on women that follows aphorism 231, Nietzsche attacks the desire of women to become independent and develop greater self-knowledge. Nietzsche writes that one of the worst developments of Europe is the female pursuit of self-reliance and the attempt to educate men on 'woman as such' (JGB 232). According to Diethe, Nietzsche throughout his oeuvre expresses disapproval for women who attempt to act as an equal to men in society. ${ }^{11}$ But, does Nietzsche not express precisely these concerns of 'men' with a certain degree of irony? For example, he writes:

Es werden schon jetzt weibliche Stimmen laut, welche, beim heiligen Aristophanes! Schrecken machen, es wird mit medizinischer Deutlichkeit gedroht, was zuerst und zuletzt das Weib vom Manne will. Ist es nicht vom schlechtesten Geschmacke, wenn das Weib sich dergestalt anschickt, wissenschaftlich zu werden? (JGB 232) ${ }^{12}$

10 Lynn Tirrell, Sexual Dualism and Women's Self-Creation: On the Advantages and Disadvantages of Reading Nietzsche for Feminists, in: Peter J. Burgard, Charlottesville/London 1994, pp. 158-182, p. 158.

11 Diethe, Nietzsche's Women: Beyond the Whip, p. 42.

12 Translation modified. 
Nietzsche explains that formerly the scientific discussion of 'woman' was only done between men and he questions whether women really want self-enlightenment (JGB 232). Further, Nietzsche asks:

Aber es will nicht Wahrheit: was liegt dem Weibe an Wahrheit! Nichts ist von Anbeginn an dem Weibe fremder, widriger, feindlicher als Wahrheit, - seine grosse Kunst ist die Lüge, seine höchste Angelegenheit ist der Schein und die Schönheit. Gestehen wir es, wir Männer: wir ehren und lieben gerade di e se Kunst und di e s en Instinkt am Weibe. (JGB 232).

In this aphorism, Nietzsche is expressing some of his male prejudices about women and, in doing so, is making a spectacle out of them. ${ }^{13} \mathrm{He}$ is pointing to the fact that men do not want women to obtain greater autonomy; men want women to remain in a "secondary role" in which their identity is defined by men. Is Nietzsche admitting that he shares the miserliness of men pointed to by Zarathustra when he accuses men of lacking generosity in Za I, Vom Freunde? At minimum, we can understand from reading this aphorism after JGB 231 that Nietzsche is poking fun at the possessive nature of men and how much they desire to maintain women in an inferior position through controlling the image of 'woman.' Even if women despise 'woman' (JGB 232) and want to change her, Nietzsche explains that men will attempt to keep her a creature of appearances and treat women like birds, "like something that has to be locked up so that it does not fly away" (JGB 237a).

In the last two aphorisms of the section ,unsere Tugenden“ in JGB, Nietzsche is not so easily read as being critical of men. In JGB 238, he states that there is a necessary hostility and antagonism between 'man and woman' and encourages men to think of women as possessions. In aphorism 239, he addresses how 'woman' is changing and claims that women are losing influence through becoming more 'equal' to men. Nietzsche writes that just as women acquire greater respect from men, they stop being as fearful of men, „das Weib, das „das Fürchten verlernt“, giebt seine weiblichsten Instinkte preis.“ (JGB 239, KSA 5.176)

The more that women become like men, Nietzsche claims, the more they degenerate and retrogress (JGB 239). Nietzsche states that in their attempts to become like men, to work as clerks and writers and discuss politics, women are relinquishing their strongest feminine attributes connected both to cultural gender roles and biological sex roles associated with birthing children (JGB 239). In this section, Nietzsche claims that being a mother is the most important role for women. He writes elsewhere that if a woman chooses another life pursuit instead of motherhood, it is likely due to some deficiency (JGB 239; 144). Nietzsche asserts that women are doing themselves a

13 Frances Nesbitt Oppel has pointed out that Nietzsche has a "literary style that is both witty and subversive." She also claims that Nietzsche's aim with his writings on woman is to destroy her, not reassert her validity in coherence with the ideological beliefs of the time. Oppel, Nietzsche on Gender: Beyond Man and Woman, Charlottesville and London, 2005, pp. 10, 15. 
disservice by attempting an impossible feat: to be like men. In JGB 239 he expresses his concern that women are rejecting the limited space that they have to obtain power (through being a wife and mother) in order to take part in work and political activities, activities that Nietzsche considers to be of a lower value (especially for women).

In JGB, Nietzsche continues with some of the same critical lines toward men that he makes in FW and $\mathrm{Za}$, in particular he asserts that men are the ones who have created the image of 'woman' and they do not want her to change. Nietzsche makes an additional contribution in JGB 231 when he admits to his own prejudices about woman and man and in doing so, invites his readers to consider theirs. In this text, Nietzsche appears to be speaking on the side of men when he appeals to his readers to stop supporting and pursuing female emancipation (JGB 239). However, he also occupies a more neutral voice when he states that men treat women as birds (JGB 237a) or when he makes observations about the dislike that women have for 'woman' (JGB 86; 232). In JGB, Nietzsche is occupying multiple voices when he writes about women. But, what can the multiple trajectories of this text contribute to his assessment of the gender troubles of friendship?

Although Nietzsche is very critical of how men approach women, he also seems to be remarkably conservative when it comes to offering his support for change in the gender roles. In FW 363 Nietzsche implies that the oppositional stances that men and women have in terms of how they love (women want to be possessed and men want to possess) allows for a compatibility between them, however tumultuous, that supports heterosexual love relationships. But, what happens if women become like men and want to act 'the master,' abandoning their natural inclination to give birth to and raise children? Nietzsche does not seem to think it is possible for women to fulfill male roles well and also be mothers and wives. Although Nietzsche acknowledges that women suffer from the adherence to male constructed gender roles, he does not think the solution is for women to attempt to be equal to, as in the same as, men.

Male desire, in Nietzsche's account, is connected to the performance of female gender roles. It follows that Nietzsche thinks women who refuse to base themselves on the finery and charms of 'woman' are less desirable to men. This poses difficulties for heterosexual love relationship if women no longer want to conform to the image of desire that men want. Would a less desirable woman be someone who is more likely to have friends, for Nietzsche, especially if she is well educated like her male companion? In FW 14 Nietzsche writes that friendship has a shared desire for an ideal instead of a drive to mutual possession. For a woman and man who are peers, an absence of possessive lust for each other should remove one obstacle to Nietzschean friendship, especially if we follow Nietzsche's reflections in MA I 390 where he states that friendship is possible for women with men with "the assistance of a slight physical antipathy." What seems certain from Nietzsche's writings on women and love is that he does not think erotic love and friendship are compatible. Is this due to Nietzsche's own limitations that he points to about himself in JGB 231 and his inability to re-evaluate erotic love? Nietzsche writes that "one must learn to love" just as "one has to learn to 
hear a figure and melody" (FW 334). When it comes to his speculations on women and love, there are some crucial melodies that he surely misses. In order to learn how to re-evaluate the gender troubles of friendship that Nietzsche exposes in his writings, we must turn to Luce Irigaray who shares Nietzsche's supposition: "Love, too, has to be learned." (FW 334)

\section{Irigaray's Re-evaluation of Love}

Instead of viewing love as an impairment to friendship as Nietzsche does, Irigaray contends that friendship requires the cultivation of love and wonder for the other. Irigaray re-evaluates the assimilating love of Nietzsche with her concept of wonder, describing wonder as "the appetite for knowledge of who or what awakens our appetite" ${ }^{14}$ that believes in "the perpetual newness of the self, the other, the world." 15 Irigaray claims that wonder is the feeling that must be maintained in friendship to allow for recognition to occur. Instead of attempting to reduce the other into a concept that one already has so that the friend can be controlled and defined, wonder pauses at the newness of the subject. Irigaray describes the subject of wonder as one that cannot be delimited, imposed upon, or conclusively defined; this is not to say the other is without an identity, instead it is one "unfinished."16

Irigaray's friend approaches the subject of wonder as one who is in perpetual becoming, never completely knowable. When friends love each other with a sense of wonder, there is greater leeway for variations in self-expression because one does not presume to know the other conclusively. One gives love to the other as an affirmation of the other's fate that acquiesces to its inevitability (beyond one's control of the other). Love, for Irigaray, becomes an expression of affirmation of the other that has emotional and rational dimensions. It includes a self-limiting move, a respect for the other, because one must admit to being unable to define the other. It also allows for one to feel delight (aesthetic, conceptual, erotic) in the threshold experience of the otherness of the other. Irigaray frames her description of love through wonder as a kind of activism because it aims to change the character of heterosexual love and friendship.

Wonder provides a pathway out of the projective and assimilative inevitabilities of what Irigaray calls "love of the same" that underlies Nietzsche's concept of love because he considers women to form themselves in an image of woman that has been created by man (FW 68). Irigaray defines love of the same as "undifferentiated

14 Luce Irigaray, An Ethics of Sexual Difference, trans. Carolyn Burke and Gillian C. Gill, London 2004, p. 67.

15 Irigaray, An Ethics of Sexual Difference, p. 70.

16 Irigaray, An Ethics of Sexual Difference, p. 95. 
attraction to the archaic, as love of that which does not and will not know itself as different." ${ }^{17}$ Love of the same presumes shared identities between friends and is a love based on "mercantile exchanges." ${ }^{18}$ Between men, Irigaray states that love of the same is impatient, incorporating, and goal-oriented and it uses the female as mediator, as a symbol of exchange between men. ${ }^{19}$ The expression of love (of the same) inhabits a vertical rather than a horizontal relationship in which intersubjective interactions involve condescension and idolatry, like the tyrant-slave relationship that Nietzsche believes is pervasive in women's lives (Za I, Vom Freunde). Irigaray explains how love of the same transforms and systemizes: "Instead of germination, birth, and growth in accordance with natural economy, man substitutes the instrument and the product ... The cultivation of nature becomes exploitation, which risks destroying the vitality of the soil." ${ }^{20}$ In a love of the same framework, rather than perceiving vulnerability between friends as an opportunity for learning and sharing, it becomes an opportunity for overpowering and assimilation (as is the predicament of love in Nietzsche's FW 14).

In a selection from I Love to You, Irigaray states that her notion of recognition in love involves marking oneself with an "incompleteness, with the negative." 21 "Recognizing you means or implies respecting you as other, accepting that I stop before you as before something insurmountable, a mystery, a freedom that will never be mine, a subjectivity that will never be mine, a mine that will never be mine."22 Irigaray argues that with a foundation of respect, the experience of wonder can be expressed as "I love to you" which resists the incorporation of two into one. Irigaray's re-evaluation of love involves bringing attention to the necessity of self-restraint, as well as appreciation for the distance that is between two people due to their unknowability. In doing so, Irigaray's notion of love denies the possessive drives associated with the male gender role in Nietzsche's works (JGB 194).

According to Nietzsche, erotic love enacts a possessive drive in which the pursuer attempts to possess his lover (FW 14). Irigaray's notion of wonder provides a necessary self-limitation for approaching the other. Yet, she also acknowledges, along with Nietzsche and Beauvoir, that female identity revolves around male entitlement. Held to the image of 'woman,' women seek to become the other of the male and, in doing so, enact and perpetuate a love framework that is assimilating. Whereas Nietzsche fails to provide remedies for the gender troubles of friendship, Irigaray suggests a re-evaluation of heterosexual love and friendship through her account of wonder and sexual difference.

17 Irigaray, An Ethics of Sexual Difference, p. 83.

18 Irigaray, An Ethics of Sexual Difference, p. 85.

19 Irigaray, An Ethics of Sexual Difference, pp. 86, 96.

20 Irigaray, An Ethics of Sexual Difference, p. 85.

21 Irigaray, Key Writings, p. 9.

22 Irigaray, Key Writings, p. 8. 
Irigaray conceives of sexual difference as the most significant and universal difference of human beings and (one of) the most serious philosophical problem of our time. She states that each person belongs to a gender, "which means to a sexuate universal and to a relation between two universals." ${ }^{23}$ Irigaray acknowledges that gender is constructed and does not necessarily correspond to sex, but she claims that this disconnect is attributed to male cultural domination. ${ }^{24}$ Women lack an understanding of difference because difference has been neutralized through a patriarchal love of the same. Relationships that arise from, but cannot be reduced to female biology, such as the mother-daughter relationship, are productive sources for generating notions of womanhood that Irigaray considers to have some levity from the patriarchal hegemony. Irigaray claims that for recognition to occur between men and women, women must find their own cultures and identities, a self-love that is not earned through their usefulness to men. Irigaray states that when the goal of feminist activism is:

[C]hange in the distribution of power, leaving intact the power structure itself, then they are resubjecting themselves, deliberately or not, to a phallocratic order. This latter gesture must of course be denounced, and with determination, since it may constitute a more subtly concealed exploitation of women. ${ }^{25}$

Obtaining a symbolically masculine status is not enough. Irigaray takes issue with the attempt of women to be like men. Irigaray is adamant that women need a history and a genealogy that is their own. She thinks male and female roles should no longer be viewed in a hierarchical schema. ${ }^{26}$ In addition to developing a self-love in which a woman views herself as both daughter and mother engaged in a reciprocating love, Irigaray thinks there are public changes that need to occur. For instance, value systems need be modified so that paternal and maternal functions are not structured hierarchically; also, love and eroticism must be connected, not disassociated. However, Irigaray's intent is not to "reify woman as mother, wife, muse, natural caregiver, sensitive companion" ${ }^{27}$ as it appears to be Nietzsche's aim in JGB 239. Irigaray states that the claim for sexual difference has been a means from which to exclude the sufficient

23 Irigaray, Key Writings, p. 10. Irigaray's notion of sexuate refers to an irreducible ontological difference in being. She believes that there are no unsexed human beings and that humans are sexuate beings in a relational mode of two.

24 "And so to be born a girl in a culture dominated by the masculine is not necessarily to be born with a sensibility appropriate to my gender. No doubt female physiology is present but not identity, which remains to be constructed" (Irigaray, Key Writings, p. 11).

25 Luce Irigaray, This Sex Which Is Not One, trans. Catherine Porter, Ithaca 1985, p. 81.

26 "And our difference cannot be reduced to one hierarchy, one genealogy, one history. It cannot be value in terms of more or less. Which would amount to annihilate it” (Irigaray, Key Writings, 9).

27 Penelope Deutscher, A Politics of Impossible Difference, Ithaca 2002, p. 48. 
development of sexual difference ${ }^{28}$ and she wants this to change. According to Irigaray, women need to be (allowed to) become a diverse social group, a multiplicity that does not presume sameness, ${ }^{29}$ and is not driven by feminine rivalry.

Irigaray claims that feminine love between women has been based on a rivalry that circulates between three poles: the "prototype of maternity" that only one can occupy, the real mother, and male desire (from son, brother, father). ${ }^{30}$ When women speak to one another, Irigaray claims they use an assimilating language that reinstates both rivalry and sameness: "like you," "me too," "me more" or "me less," and "just like everyone else." ${ }^{31}$ Irigaray explains that women measure each other under a masculine hegemony, what Nietzsche calls the image of woman created by man (FW 68), reducing each other into "a sameness that is not their own," and in doing so are instruments of their own oppression. ${ }^{32}$ When women 'love' each other within this framework they do not love the other for who she is but rather for that place she occupies (as desirable, as an ideal of maternity, etc.). ${ }^{33}$ In order for this to shift, women must learn to take critical distance from their gender roles and develop new kinds of female identities. ${ }^{34}$ Irigaray considers the "epistemological threshold" 35 of difference to be most decipherable between the male-female relationships and locates this arena as the one that is fertile for the transformation of values. Through a "labor of the negative," one perceives limitation and, in doing so, gives birth to new possibilities. ${ }^{36}$

The development of wonder between friends and lovers challenges the positivistic approach to knowledge because it rejects the presumption that complete intersubjective knowing is possible or desirable. Wonder accepts the impossibility of sameness and views the inter-relations of friends as an opportunity for sharing that generates greater mutual understanding. Irigaray states that when we approach something that still has mystery for us we feel "astonishment, wonder, praise, sometimes questioning, but not reproduction, repetition, control, appropriation." ${ }^{37}$ Kelly Oliver points out that for Irigaray, it is the movement of realizing that one cannot know the other that allows for relationships to live outside of a space ruled by power struggles and the need for domination. ${ }^{38}$ This is why Irigaray finds it so important to

28 Deutscher, A Politics of Impossible Difference, p. 49

29 Irigaray, An Ethics of Sexual Difference, pp. 57-8.

30 Irigaray, An Ethics of Sexual Difference, p. 87.

31 Irigaray, An Ethics of Sexual Difference, p. 88.

32 Irigaray, An Ethics of Sexual Difference, p. 88.

33 Irigaray, An Ethics of Sexual Difference, p. 89.

34 Irigaray, An Ethics of Sexual Difference, p. 93.

35 Gourgouris Stathis, Autonomy, Self-Alteration, Sexual Difference, in: Elena Tzelepis / Athena Athanasiou (eds.), Rewriting Difference, Albany 2010, pp. 135-148, p. 140.

36 Kelly Oliver, Vision, Recognition, and a Passion for the Elements, in: Maria Cimitile / Elain Miller (eds.), Returning to Irigaray, Albany 2007, pp. 121-135, p. 131.

37 Irigaray, Key Writings, p. 23.

38 Oliver, Vision, Recognition, and a Passion for the Elements, p. 132. 
cultivate wonder in human relationships: by refusing to see the other as part of one's own universe, one's obscurity is given room to be expressed and perceived by others, thereby opening the possibility for greater intimacy. ${ }^{39}$

In Vermischte Meinungen und Sprüche, Nietzsche also seems to understand the necessity of practicing self-limitation in love. „Was ist denn Liebe anders als verstehen und sich darüber freuen, dass ein Andrer in andrer und entgegengesetzter Weise, als wir, lebt, wirkt und empfindet? Damit die Liebe die Gegensätze durch Freude überbrücke, darf sie dieselben nicht aufheben, nicht leugnen.“ (MA II, VM 75) Yet, in his later texts when speaking about love (FW, Za, JGB) Nietzsche's focus shifts to the predilection of (male) lovers to incorporate the loved one, to seek out that which is most familiar and to view the other as an extension of one's owns tastes and interests. A greedy lover in FW 14 is analogous to a knowledge-seeker who fails to engage his intellectual conscience (FW 335) because both follow their impulses without self-reflection and pursue those ends that appear to be the most convenient.

Irigaray problematizes the presumption of 'knowing' the other as an end that presumes learning is finished. Both men and women are restricted by their presumptions about each other, but women are doubly limited because they view themselves through a model that has not been produced by them. Nietzsche appears to agree with this view in FW 68 when he writes that woman forms herself according to the image of woman created by man. Irigaray emphasizes the need for women to develop more female-centered knowledge sources, specifically a genealogy and a culture from which to develop self-understanding.

\section{Conclusion: Bringing Wonder to Love in the Spirit of Friendship}

The Nietzschean question remains whether the propensity to projection and assimilation in love can be rectified through wonder. Can the assimilating drive of love, which is an expression of the will to power for Nietzsche, be mediated through the activation of wonder as described by Irigaray? Or do the impulses of erotic love that are reified through culturally entrenched gender roles require more than a self-limiting move that expresses an open-ended love to the otherness of the other? If Nietzsche were to attempt to overcome the gender troubles of friendship, which have their sources in love, it is more likely that he would recommend the exercising of the intellectual conscience, what Nietzsche explains as a conscience behind the conscience which

39 "To include the other in my universe prevents meeting with the other, whereas safeguarding the obscurity and the silence that the other remains for me aids in discovering proximity" (Irigaray, Key Writings, p. 29). 
engages in a second order of self-questioning (FW 2; 335). In other words, he would advocate discipline and self-observation during the passionate pursuit of knowledge rather than self-restraint in the cultivation of wonder.

When Irigaray discusses how we reason and love she acknowledges that we have been educated to do so as an appropriation. ${ }^{40}$ She claims that the pursuit of knowledge of a concept or a person involves a method of learning in which one attempts to control and dominate information so that it becomes decipherable to the knowledge-seeker. Irigaray explains that in the attempt to understand the other there is often a refusal to accept limitations even when limits are shown necessary for co-existence and co-creation..$^{41}$ Irigaray goes so far as to associate the attempt to make things definitively knowable with a totalizing action that is synonymous to death: "We do not see that this gesture transforms the life of the world into something finished, dead, because the world thus loses its own life, a life always foreign to us, exterior to us, other than us." ${ }^{22}$ In Irigaray's terms, the attempt to definitively know the other means that recognition fails because one makes the other symbolically "dead." In order to bring life back and learn how to include wonder in the experience of love, one must first understand that there is no final solution or answer to knowing, one must learn how to habituate the labor of the negative or "vigilant self-limitation." 43

Irigaray's approach to knowledge shares with Nietzsche the belief that discipline is important for wisdom; however, as noted above, in Nietzsche's account it is the engagement of the intellectual conscience that motivates questioning and restraint (FW 2; 335), not a sense of wonder for the subject of interest. More importantly, Nietzsche does not consider the relevance of employing the intellectual conscience when it comes to matters of love. He makes a clear delineation between the emotional and physical impulses of love relations versus the intellectual and creative potentials of friendship (FW 14). Irigaray's attempt to bring friendship into love is not seriously considered by Nietzsche because he believes that the selfish and instinctual greed of love destroys one's ability to approach the other with the measure required for a good friendship.

Die gute Freundschaft entsteht, wenn man den Anderen sehr achtet und zwar mehr als sich selbst, wenn man ebenfalls ihn liebt, jedoch nicht so sehr als sich, und wenn man endlich, zur Erleichterung des Verkehrs, den zarten Anstrich und Flaum der Intimität hinzuzuthun versteht, zugleich aber sich der wirklichen und eigentlichen Intimität und der Verwechselung von Ich und Du weislich enthält. (MA II, VM 241)

40 Irigaray, Key Writings, p. 23.

41 Irigaray, Key Writings, p. 25.

42 Irigaray, Key Writings, p. 23.

43 Oliver, Vision, Recognition, and a Passion for the Elements, p. 133. 
For Nietzsche, friendship resists assimilations to a degree that is not possible in love. Yet, Nietzsche and Irigaray also appear to share in the opinion that assimilation always happens in human relationships. Perhaps a more realistic question to ask is: can we assimilate more ethically? This question suggests that even with the experiences of projection and assimilation some recognition occurs precisely because the other always exceeds incorporation. As Irigaray writes, "one sex is not entirely consumable by the other. There is always a remainder." ${ }^{44}$ When writing about Irigaray and the problem of assimilation, Penelope Deutscher and Catherine Peebles point to Derrida's claim that assimilation or cannibalization of the other is inevitable, but also impossible. ${ }^{45}$ Assimilation is impossible because one can never completely make the other one's own: there is always some excess or "remainder." Although Irigaray is attempting to cultivate an ethics that moves away from incorporation, she remains aware of its prevalence; however, her notion of sexual difference means that she, like Derrida, does not think one's projections have the capacity to swallow the other completely (although they do modify the other). For example, even within a love of the same, when a woman becomes a mirror to her male lover, reflecting back to him an image of 'woman' that he has created, she is restrained through this experience, but Irigaray does not think she is reducible to the experience or his image of her.

In fact, it is precisely by way of the failures to become that perfect mother or object of desire that women create breaks in what their gender is perceived to be and from this, open themselves up to new possibilities. "In the case of Irigaray's ethics, nondigestion is the emblem of a greater fidelity to the other, a better recognition of the other's difference." ${ }^{46}$ When he cannot understand her and when she does not become synonymous with his expectations, it indicates a new becoming. In Nietzschean terms we can explain the failures of the drive towards incorporation through his analysis of the will to power. When there is a struggle between two forces no matter the difference in level of power, both forces will influence and modify the other (Za II, Von der Selbst-Ueberwindung). The hope for Irigaray is that within these failures and modifications, the lover-friends learn how to love with a sense of wonder that resists love of the same.

Nietzsche provides a provocative and critical view of love that helps us to consider the extent to which love and friendship are shaped by gender constructs and inequalities. He identifies the power disparities between men and women and how women are exploited by men. Nietzsche suggests that the love that directs relationships advantages men and harms women. Yet, in Nietzsche's writings on love the only

44 Irigaray, An Ethics of Sexual Difference, p. 14.

45 Deutscher, A Politics of Impossible Difference, p. 133; Catherine Peebles, Knowing the Other: Ethics and the Future of Psychoanalysis, in: Maria Cimitile / Elain Miller (eds.), Returning to Irigaray, Albany 2007, pp. 223-241, p. 236.

46 Deutscher, A Politics of Impossible Difference, p. 132. 
source for recognition open to women is through being esteemed for some fulfillment of their gender roles. Nietzsche's woman is not given the opportunity to consider what she might be outside of a world that is defined by men. Nietzsche points to a lack of generosity of men: men deny women an access to the powers that would allow them to develop female sources of self, undetermined by their relationship to men. Nietzsche's observations on the perils and comedies of love and the gender roles performed around love help to elucidate the gender troubles of friendship. Yet he offers no substantial suggestions on how to improve the "psychic knot" (FW 71) that women must grapple with when it comes to navigating love relationships or attempting to be friends.

In order to learn how to love with a greater sense of mutual understanding, we must look to Irigaray whose notion of wonder provides new pathways from which to pursue a love that is less assimilating. One of Irigaray's most vital contributions to developing a richer notion of intersubjective recognition that includes love relationships and friendship between men and women is her belief that we must relinquish the need to definitively know the other. This opens up friendship to a more generative sharing. Irigaray's concept of wonder encourages one to pause at the other; it resists projection. Wonder acknowledges the notion of respect as self-limitation and utilizes this concept alongside love to foster greater self-knowledge and understanding of the other in friendship. 